University of Nebraska - Lincoln

DigitalCommons@University of Nebraska - Lincoln

USGS Staff - Published Research

US Geological Survey

2008

\title{
The Ecological Future of the North American Bison: Conceiving Long-Term, Large-Scale Conservation of Wildlife
}

\author{
Eric W. Sanderson \\ Wildlife Conservation Society, esanderson@wcs.org \\ Kent H. Redford \\ Wildlife Conservation Society, kredford@wcs.org \\ Bill Weber \\ Wildlife Conservation Society, bweber@wcs.org \\ Keith Aune \\ Montana Department of Fish, Wildlife and Parks \\ Dick Baldes \\ Wind River Alliance, rbaldes@wyoming.com \\ See next page for additional authors
}

Follow this and additional works at: https://digitalcommons.unl.edu/usgsstaffpub

Sanderson, Eric W.; Redford, Kent H.; Weber, Bill; Aune, Keith; Baldes, Dick; Berger, Joel; Carter, Dave; Curtin, Charles; Derr, James N.; Dobrott, Steve; Fearn, Eva; Fleener, Craig; Forrest, Steve; Gerlach, Craig; Gates, C. Cormack; Gross, John E.; Gogan, Peter; Grassel, Shaun; Hilty, Jodi A.; Jensen, Marv; Kunkel, Kyran; Lammers, Duane; List, Rurik; Minkowski, Karen; Olson, Tom; Pague, Chris; Robertson, Paul B.; and Stephenson, Bob, "The Ecological Future of the North American Bison: Conceiving Long-Term, Large-Scale Conservation of Wildlife" (2008). USGS Staff -- Published Research. 608.

https://digitalcommons.unl.edu/usgsstaffpub/608

This Article is brought to you for free and open access by the US Geological Survey at DigitalCommons@University of Nebraska - Lincoln. It has been accepted for inclusion in USGS Staff -- Published Research by an authorized administrator of DigitalCommons@University of Nebraska - Lincoln. 


\section{Authors}

Eric W. Sanderson, Kent H. Redford, Bill Weber, Keith Aune, Dick Baldes, Joel Berger, Dave Carter, Charles Curtin, James N. Derr, Steve Dobrott, Eva Fearn, Craig Fleener, Steve Forrest, Craig Gerlach, C. Cormack Gates, John E. Gross, Peter Gogan, Shaun Grassel, Jodi A. Hilty, Marv Jensen, Kyran Kunkel, Duane Lammers, Rurik List, Karen Minkowski, Tom Olson, Chris Pague, Paul B. Robertson, and Bob Stephenson 


\title{
The Ecological Future of the North American Bison: Conceiving Long-Term, Large-Scale Conservation of Wildlife
}

\author{
ERIC W. SANDERSON $,{ }^{a}, *$ KENT H. REDFORD,${ }^{a}$ BILL WEBER,${ }^{a}$ KEITH AUNE,${ }^{b}$ DICK BALDES,${ }^{c}$ \\ JOEL BERGER,${ }^{a}{ }^{\dagger}$ DAVE CARTER,${ }^{d}$ CHARLES CURTIN,${ }^{e}$ JAMES DERR,${ }^{f}$ STEVE DOBROTT,${ }^{g}$ \\ EVA FEARN,${ }^{a}$ CRAIG FLEENER, ${ }^{b}$ STEVE FORREST,${ }^{i}$ CRAIG GERLACH ${ }^{j}$ C. CORMACK GATES,${ }^{k}$ \\ JOHN E. GROSS, ${ }^{l}$ PETER GOGAN,${ }^{m}$ SHAUN GRASSEL,${ }^{n}$ JODI A. HILTY,${ }^{a}$ MARV JENSEN, ${ }^{o}$
} KYRAN KUNKEL,${ }^{i}$ DUANE LAMMERS,${ }^{p}$ RURIK LIST,${ }^{q}$ KAREN MINKOWSKI,${ }^{a}$ TOM OLSON,${ }^{r}$ CHRIS PAGUE,${ }^{s}$ PAUL B. ROBERTSON,${ }^{s}$ AND BOB STEPHENSON ${ }^{t}$

${ }^{a}$ Wildlife Conservation Society, 2300 Southern Boulevard, Bronx, NY 10460, U.S.A.

${ }^{b}$ Montana Department of Fish, Wildlife and Parks, 1420 East Sixth Avenue, Helena, MT 59620, U.S.A.

${ }^{c}$ Wind River Alliance, P.O. Box 888, Fort Washakie, WY 82514, U.S.A.

${ }^{d}$ National Bison Association, 1400 W. 122nd Avenue, No. 106, Westminister, CO 80234, U.S.A.

${ }^{e}$ Arid Lands Project, Box 29 Animas, NM 88020, U.S.A.

${ }^{f}$ Texas A\&M University, Department of Veterinary Pathobiology, College Station, TX 77843, U.S.A.

${ }^{g}$ Ladder Ranch, HC 31 Box 95, Caballo, NM 87931, U.S.A.

${ }^{b}$ Council of Athabascan Tribal Governments, 113 Angel Pond Subdivision, Fort Yukon, AK 99740, U.S.A.

${ }^{i}$ World Wildlife Fund-US, Northern Great Plains Program, P.O. Box 7276, Bozeman, MT 59771, U.S.A.

${ }^{j}$ University of Alaska Fairbanks, Eielson 309, Fairbanks, AK 99775, U.S.A.

${ }^{k}$ University of Calgary, Faculty of Environmental Design, 2500 University Drive NW, Calgary, Alberta T2N 1N4, Canada

${ }^{l}$ National Park Service, Inventory and Monitoring Program, 1201 Oakridge Drive, Suite 150, Ft. Collins, CO 80525, U.S.A.

${ }^{m}$ USGS-Northern Rocky Mountain Science Center, Forestry Sciences Lab, Montana State University, Bozeman, MT 59717, U.S.A.

${ }^{n}$ Lower Brule Sioux Tribe, 187 Oyate Circle, Lower Brule, SD 57548, U.S.A.

${ }^{\circ}$ Vermejo Park Ranch, P.O. Drawer E, Raton, NM 87740, U.S.A.

$p 777$ Buffalo Ranch, Hermosa, SD 57744, U.S.A.

${ }^{q}$ Instituto de Ecología, Universidad Nacional Autonoma de Mexico, A.P. 70-275, 04510 Mexico D.F., Mexico.

${ }^{r}$ Box 250, Bragg Creek, AB TOL OK0, Canada

${ }^{s}$ The Nature Conservancy, 2424 Spruce Street, Boulder, CO 80302, U.S.A.

${ }^{t}$ Alaska Department of Fish and Game/Wildlife Conservation, 1300 College Road, Fairbanks, AK 99701, U.S.A.

\begin{abstract}
Many wide-ranging mammal species have experienced significant declines over the last 200 years; restoring these species will require long-term, large-scale recovery efforts. We bighlight 5 attributes of a recent range-wide vision-setting exercise for ecological recovery of the North American bison (Bison bison) that are broadly applicable to other species and restoration targets. The result of the exercise, the "Vermejo Statement" on bison restoration, is explicitly (1) large scale, (2) long term, (3) inclusive, (4) fulfilling of different values, and (5) ambitious. It reads, in part, "Over the next century, the ecological recovery of the North American bison will occur when multiple large berds move freely across extensive landscapes within all major habitats of their historic range, interacting in ecologically significant ways with the fullest possible set of other native species, and inspiring, sustaining and connecting buman cultures." We refined the vision into a scorecard that illustrates how individual bison herds can contribute to the vision. We also developed a set of maps and
\end{abstract}

*email esanderson@wcs.org

†Current address: Organismal Biology and Ecology, University of Montana, Missoula, MT 59812, U.S.A.

Paper submitted February 11, 2007; revised manuscript accepted August 21, 2007. 
analyzed the current and potential future distributions of bison on the basis of expert assessment. Although more than 500,000 bison exist in North America today, we estimated they occupy $<1 \%$ of their bistorical range and in no place express the full range of ecological and social values of previous times. By formulating an inclusive, affirmative, and specific vision through consultation with a wide range of stakeholders, we bope to provide a foundation for conservation of bison, and other wide-ranging species, over the next 100 years.

Keywords: Bison bison, conservation goals, ecological representation, species conservation planning, the Vermejo Statement

El Futuro Ecológico del Bisonte de Norte América: Concepción de la Conservación de Vida Silvestre a Largo Plazo y a Gran Escala

Resumen: Muchas especies de mamíferos de distribución amplia ban experimentado declinaciones significativas durante los últimos 200 años; la restauración de estas especies requerirá esfuerzos de recuperación a largo plazo y a gran escala. Resaltamos 5 atributos de un reciente ejercicio de gran visión para la recuperación ecologica del bisonte de Norte América (Bison bison) que son aplicables en lo general a otras especies y objetivos de restauración. El resultado del ejercicio, la "Declaración de Vermejo", explícitamente es (1) de gran escala, (2) de largo plazo, (3) incluyente, (4) satisfactor de valores diferentes y (5) ambicioso. En parte, establece que "En el próximo siglo, la recuperación ecológica del Bisonte de Norte América ocurrirá cuando múltiples manadas se desplacen libremente en los extensos paisajes de todos los hábitats importantes en su rango de distribución bistórica, interactúen de manera significativa ecológicamente con el conjunto más completo de otras especies nativas e inspiren, sostengan y conecten culturas humanas." Refinamos esta visión en una tarjeta de puntuación que ilustra cómo las manadas de bisonte individuales pueden contribuir a la visión. También desarrollamos un conjunto de mapas y analizamos las distribuciones actuales y potencialmente futuras del bisonte con base en la evaluación de expertos. Aunque actualmente existen más de 500,000 bisontes en Norte América, estimamos que ocupan $<1 \%$ de su distribución bistórica y no expresan el rango completo de valores ecológicos y culturales de otros tiempos. Mediante la formulación de una visión incluyente, afirmativa y específica basada en la consulta a una amplia gama de interesados, esperamos proporcionar un fundamento para la conservación del bisonte, y otras especies de distribución amplia, para los próximos 100 años.

Palabras Clave: Bison bison, conservación de especies, Declaración de Vermejo, metas de conservación, representación ecológica

\section{Introduction}

Many important, wide-ranging mammals have experienced significant range collapses in recent history. Within the last 150 years in North America, for example, elk have lost $74 \%$ of their range, pronghorn $64 \%$, grizzly bear 53\%, black bear 39\%, and caribou 24\% (Laliberte \& Ripple 2004). Similar declines have been observed for elephants, lions, jaguars, tigers, wild dogs, guanacos, wild cattle, and many other wide-ranging wildlife species from around the world (MacDonald 2006). The familiar factors of habitat loss and fragmentation, degraded ecosystems, competition with humans and human commensals, and overharvest explain most of these declines.

Many of these species are also the animals that matter most to people. They provide inspiration for human art and story-telling (Shepard 1996), sustain human livelihoods directly or indirectly (Reynolds et al. 2001), and perform essential ecological functions (Marcot \& Vander Heyden 2001). Staples of zoological parks and children's toys worldwide, these familiar species help draw over 143 million people per year to zoos in the United States (AZA 2006) and sustain a global wildlife tourism indus- try that generates billions of dollars annually in direct and indirect economies (Freese 1998). Moreover, these same animals are useful as conservation planning tools; Sanderson et al. (2002a) summarized the case for these "landscape species" in strategies to conserve large, wild ecosystems.

In attempting to understand why species of such ecological and social importance have declined so dramatically, the North American bison makes a useful case study. (Here, bison refers to both subspecies together [Bison bison bison, wood bison, and Bison bison atbabascae, plains bison, both of which are commonly called "buffalo" [Reynolds et al. 2003].) Three hundred years ago, bison ranged across the Great Plains in the tens of millions (Shaw 2000), reached from the Arctic Circle to Mexico and from Oregon to New Jersey (Hall \& Kelson 1959), and were essential to the ecology of grassland systems and the economies and spiritual lives of the people that dwelled in those grasslands and other places (Haines 1995). Bison wallowed, rubbed, pounded, and grazed the prairies into heterogeneous ecological habitats; they converted vegetation into protein biomass for predators, including people; and they shaped the way fire, water, 
Table 1. Ecological functions of North American bison.

Creation of landscape heterogeneity through grazing and wallowing

Nutrient redistribution

Interaction with hydrological processes

Competition with other ungulates (e.g., elk, mule deer, caribou, moose)

Prey for wolves, grizzly bear, and humans

Habitat creation for grassland birds, prairie dogs, and other commensals

(e.g., black-footed ferret)

Provision of carcasses for scavengers and as a localized nutrient source

Opened access to vegetation through snow cover

Modification of and use of fire regimes

Disturbance of woody vegetation by rubbing

Provision of bison wool for small mammals and nesting birds
Coppedge et al. 1999

Frank \& Evans 1997

Coppedge et al. 1999

Fischer \& Gates 2005

Haines 1995; Smith et al. 2000

Johnsgard 2005

Green et al. 1997; Towne 2000

Hawley \& Reynolds 1987

Fuhlendorf \& Engle 2001

Coppedge \& Shaw 1997

Coppedge 1997 soil, and energy moved across the landscape (Knapp et al. 1999; Table 1.) During European colonization, bison provided meat and hide and indirectly facilitated industrialization by providing leather for machinery belts (Isenberg 2000).

By the late 19th century these factors had driven the bison nearly to extinction in the wild (Hornaday 1889) and, with them, the Native American communities that once depended on bison for their survival (Haines 1995). Through a remarkable series of efforts, starting with private individuals, conservation groups (notably the American Bison Society) and government, then later, private landowners and ranchers and, most recently, tribal nations, the continental bison population has recovered substantially (Isenberg 2000; Weber 2006). Today, there are more than 500,000 bison in North America, the species is no longer in danger of demographic extinction, and a market exists for their sustainable use (NBA 2006). This history is heralded around the world as a landmark success of the conservation movement (Waldman 2001; U.S. Department of State 2006).

Recently, however, some conservationists have begun to wonder whether bison restoration has been such a great success (Freese et al. 2007). Today most bison are raised for meat production, selectively bred, mixed with cattle genes, separated from natural predators, and managed as small herds in fenced paddocks. The majority of bison no longer play the significant roles they once did in grasslands and other ecosystems-they do not compete with other grazers, interact with wild predators, or shape landscapes. Because of introduced cattle diseases, stringent regulations dramatically limit where bison can roam or be moved. In some jurisdictions bison are livestock, in others, wildlife, and this distinction governs how the bison are managed.

Thus, one asks the following questions. What is our vision for bison restoration? Is it the animal itself-whether in parks, zoos, or ranches-or is it also the interactions between bison and their environment that need to be conserved? At what scale and through which geographies should bison be restored? What aspects of the hu- man relationship to bison-economic, cultural, aesthetic, spiritual-should be restored? These questions transcend science and enter into the realm of ethics, politics, and morality; yet, they lie at the heart of what conservationists hope to achieve not just for bison, but for other species and ecosystems as well.

Here we have grappled with these matters and produced a vision of what broad-scale wildlife restoration should ideally encompass. (We define restoration as "the process of assisting the recovery of an ecosystem that has been degraded, damaged, or destroyed" [SER 2004].) Our work follows other efforts that seek to conceive large-scale visions for conservation and to understand the conditions that make such conception possible (Soulé \& Terborgh 1999; Manning et al. 2006). We highlight 5 attributes of our vision that could be applied to other conservation targets and describe a set of supporting documents (maps, databases, and a scorecard) that bring the vision into sharper focus.

\section{The Ecological Future of the North American Bison}

In 2005-2006 the Wildlife Conservation Society hosted 3 meetings to set a vision for the ecological future of the North American bison (Redford \& Fearn 2006). The second meeting, at the Vermejo Park Ranch in northern New Mexico, led to what is known as the "Vermejo Statement." Jointly written by the authors of this paper, drawing members from indigenous groups, bison producers, conservation organizations, and government and private land managers, from throughout North America, the Vermejo Statement reads:

Over the next century, the ecological recovery of the North American bison will occur when multiple large herds move freely across extensive landscapes within all major habitats of their historic range, interacting in ecologically significant ways with the fullest possible set of other native species, and inspiring, sustaining and connecting human cultures. 
This vision will be realized through a collaborative process engaging a broad range of public, private, and indigenous partners who contribute to bison recovery by:

\begin{abstract}
Maintaining herds that meet the criteria for ecological recovery, as well as herds that contribute in some significant way to the overall vision, regardless of size;

Managing herds for the long-term maintenance of health, genetic diversity, and integrity of the species;

Restoring native ecosystems, ecological interactions, and species,

Providing conservation incentives for bison producers, managers, and other stakeholders;

Creating education, awareness and outreach programs to public and policy-making constituencies;

Building capacity among key stakeholder groups; and

Working across international borders, where necessary.
\end{abstract}

There are 5 key attributes of this statement that make it applicable to the conservation of other wide-ranging species. The statement is (1) large scale, (2) long term, (3) inclusive, (4) fulfilling of different values, and (5) ambitious. These attributes create opportunities and challenges for species conservation, as we describe later.

\section{Large Scale}

The range-wide conservation of the North American bison, like that for any wide-ranging species, will be accomplished only through the powerful aggregation of local conservation efforts. At the moment, however, as with the conservation of many species, the bison's conservation situation is rife with local disputes, entrenched factions, and seemingly intractable problems. A short but incomplete list of controversial situations simmering today includes brucellosis management in Yellowstone National Park; challenges to efforts to reintroduce bison in Alaska; the transboundary Janos herd that may be walled off from crossing between Mexico and the United States; selective breeding and domestication of bison for market; competition between bison producers and cattle ranchers; ecological competition between reintroduced wood bison and other native (and hunted) ungulates in northern Canada; bovine tuberculosis and brucellosis spreading from the Wood Buffalo National Park herd; the prerogatives of tribal nations versus government authorities in setting bison policy; the dichotomous legal status of bison as livestock or wildlife depending on jurisdiction; the introgression of cattle genes into bison; and the contested role of who-easterners or westerners, ranchers or conservationists, private individuals or government institutions, tribal nations or European descendents-is allowed to speak for conservation of the bison.

Any one of these local controversies, if allowed to dominate, could deflate the momentum for range-wide efforts and leave the entire effort stalled in a tyranny of local disagreement. Acknowledging these difficult situations, not papering over them, is essential to move forward. Equally important is the need to rise above them, to set the vision not for any one place but to share a vision that embraces the entire historical range in its ecological diversity. Such a vision places each of these controversies in its particular historical, cultural, and ecological context and creates a framework for seeking new solutions to local constraints.

We used a modified form of the range-wide prioritysetting methodology (Sanderson et al. 2002b) to create maps that define the contexts for representation, resiliency, and redundancy (Shaffer \& Stein 2000). The historical range (circa 1500) of the species spanned from Alaska to Mexico and included areas as far east as New York and as far west as California, an area estimated at 9.4 million $\mathrm{km}^{2}$ (modified from Hall \& Kelson [1959]; Fig. 1). Because there is some dispute about the stability of the historical distribution east of the Mississippi (cf. Rostlund 1960), we delineated eastern areas separately; the western part of the range alone totals 7.9 million $\mathrm{km}^{2}$.

Within the historical range, we mapped a set of $22 \mathrm{ma}$ jor habitat types by combining the ecoregions of North America (Ricketts et al. 1999) into larger units representative of the major ecological circumstances of bison (Table 2; Fig. 1). This map defines the phrase "across all major habitat types" in the Vermejo Statement. Bison are not only a species of grasslands, they also inhabit forests, steppes, and even tundra. Figure 1 illustrates this distribution and creates the opportunity for more refined visions at the ecoregional scale (e.g., Forrest et al. 2004).

\section{Long Term}

The Vermejo Statement is explicitly long term; it is defined "over the next century." As with taking a large-scale perspective, a vision that is long-term can transcend local circumstances because, as history has shown, circumstances can change dramatically over the course of a century. No one believes there will be "multiple large herds, moving across extensive landscapes in all major habitat types across the historical range" within the next 10 years. Nevertheless, it is possible this might happen within 100 years. Adopting a long-term perspective opens up conversations that might not otherwise be possible. It also opens up new complications, particularly as the evidence for the ecological impacts of climate change mounts (Parmesan 2006), undercutting the use of historical precedents for ecological potential. As yet however, climate-change models do not provide sufficient resolution to forecast what the ecological future will be for bison or other wildlife species; thus, for the moment it seems the best one can do is note that over the next 100 years, the vision will need to adapt, as the bison adapt, to the exigencies of new climatic regimes (as well as new population, economic, and political circumstances).

Figure 1 shows an estimate of the current distribution of existing bison herds within Canada, the United States, 

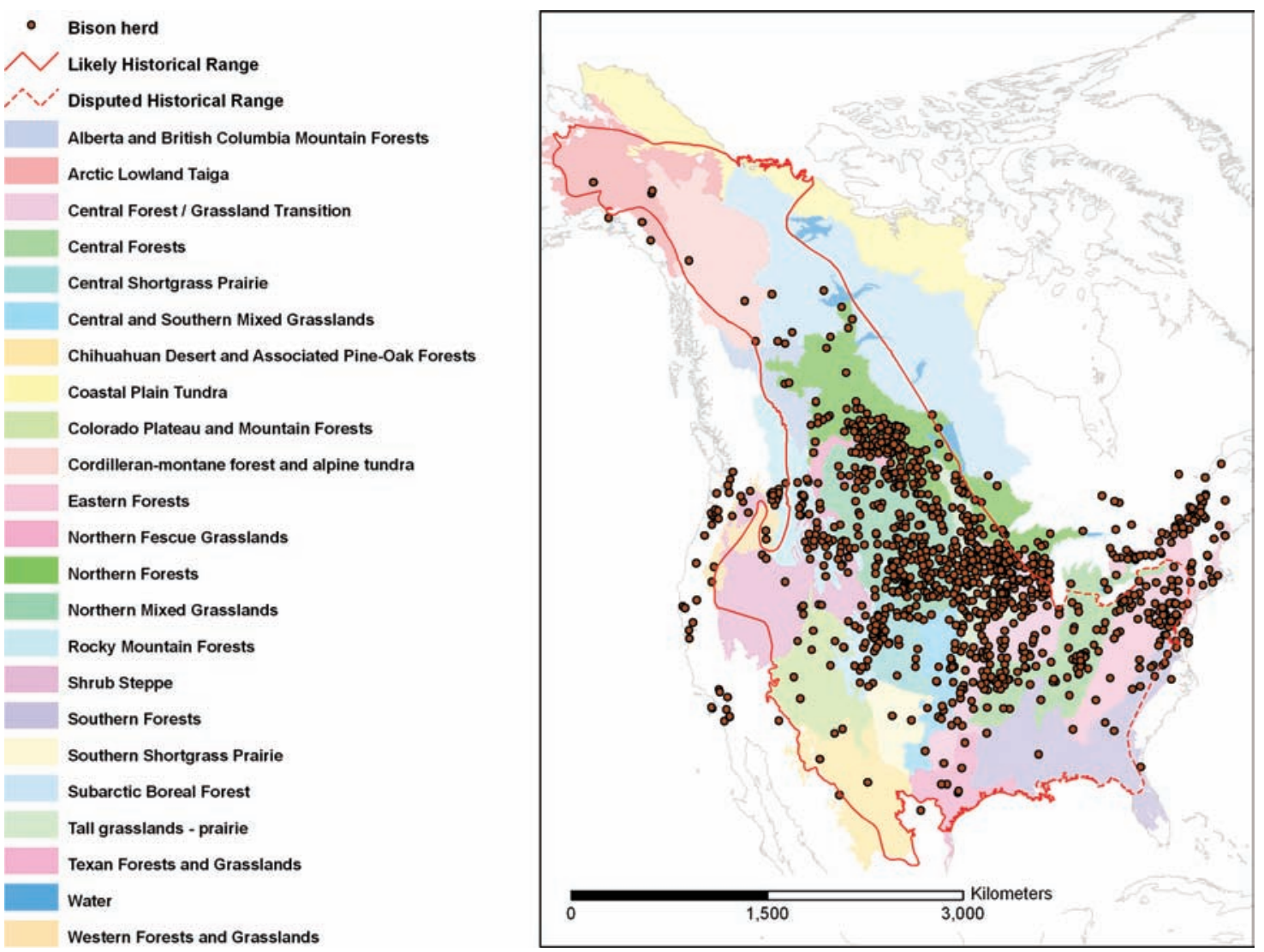

Figure 1. Distribution of a sample of existing American bison herds across the historical range (and beyond) in North America. The size of the dots overestimates the actual area occupied. Best estimates are that bison currently occupy $<1 \%$ of their circa 1500 historical range (modified from Hall \& Kelson 1959), shown in red. Major habitat types are indicated by colored areas in the background.

and Mexico. We developed this database from (1) the location of individual ranches, drawn from a review of publicly available Internet Web sites of regional bison associations, (2) an update of the Boyd (2003) review of conservation herds, and (3) contributions from the authors. Herds described from the Internet were geolocated with street addresses from Teleatlas (Boston, Massachusetts) and NAC Geographic Products (Toronto, Ontario) databases. We ignored addresses that were not the actual location of the herd (e.g., ranches headquartered in large cities). Herds were attributed by ranch size, number of animals, sex ratio, adult:calf ratio, and economic use when this information was available. The median area of ranches in our database was 405 ha (1000 acres). We assumed this median value for ranches without data. The National Bison Association (2006) estimates there are more than 4000 ranches holding bison in North America.

The 1236 herds are distributed across all but one (the Arctic Coastal Plain) of the 22 major habitat types within the historical range (Fig. 1; Table 2), with a concentration in the central grasslands of the continent. Although firm estimates are difficult to obtain because the areas of individual private holdings are not available in accessible national databases, the current range of bison is likely $<1 \%$ of the area of the species historical distribution.

The current expansive, but highly fragmented, distribution is the result of the last 100 years of conservation and commercial efforts. Looking forward the next 100 years, we mapped potential recovery areas west of the Mississippi River (Fig. 2). We mapped areas "where ecological recovery might be possible" over 3 time frames and considered future trends in land use, economic development, demography, and climate. These areas can be thought of as "stretch goals"-inspirational, ambitious, long-term goals that challenge those involved to achieve what currently seems impossible (Manning et al. 2006). They are not meant to be predictions, or prescriptions, in any absolute sense; rather, they provide a subjective, visual hypothesis of where the most promising places for ecological recovery might be. We used the human footprint to compare these recovery areas with the percentages of land area that are currently developed within each habitat type (Table 2). In only one case (tallgrass prairie) were our "stretch goals" for the next century larger than the current area of sparsely developed, "wild" lands in the same ecoregion, meaning that given the consent 
Table 2. Distribution of existing herds, current development status, and potential recovery zones across major habitat types of North American bison.

\begin{tabular}{|c|c|c|c|c|c|c|c|c|}
\hline \multirow[b]{2}{*}{ Major habitat types } & \multirow{2}{*}{$\begin{array}{l}\text { Total } \\
\text { number } \\
\text { of } \\
\text { berds }\end{array}$} & \multirow{2}{*}{$\begin{array}{l}\text { Total area } \\
\text { of potential } \\
\text { babitat } \\
\text { type }\left(\mathrm{km}^{2}\right)\end{array}$} & \multicolumn{3}{|c|}{$\begin{array}{c}\text { Current buman } \\
\text { influence levels } \\
\text { (percentage of }^{\text {babitat area) }}{ }^{a}\end{array}$} & \multicolumn{3}{|c|}{$\begin{array}{c}\text { Potential recovery } \\
\text { (cumulative percentage of } \\
\text { of habitat area) }{ }^{b}\end{array}$} \\
\hline & & & $0-9$ & $10-25$ & $26-72$ & $\begin{array}{c}\text { next } 20 \\
\text { years }\end{array}$ & $\begin{array}{l}20-50 \\
\text { years }\end{array}$ & $\begin{array}{c}50-100 \\
\text { years }\end{array}$ \\
\hline Alberta and British Columbia mountain forests & 2 & 182,501 & 91 & 9 & $<0.5$ & $\sim 1$ & $\sim 10$ & $\sim 12$ \\
\hline Arctic lowland taiga & 3 & 505,430 & 97 & 3 & $<0.5$ & $\sim 3$ & $\sim 15$ & $\sim 30$ \\
\hline Central shortgrass prairie & 54 & 256,570 & 65 & 30 & 5 & $\sim 5$ & $\sim 6$ & $\sim 16$ \\
\hline Central and southern mixed grasslands & 20 & 262,420 & 32 & 58 & 10 & - & - & $\sim 1$ \\
\hline Chihuahuan desert and associated pine-oak forests & 4 & 438,175 & 72 & 27 & 2 & $\sim 3$ & $\sim 15$ & $\sim 26$ \\
\hline Coastal plain tundra & 0 & 140,406 & 99 & 1 & $<0.5$ & - & - & - \\
\hline Colorado plateau and mountain forests & 8 & 464,723 & 78 & 20 & 1 & - & - & $\sim 20$ \\
\hline Cordilleran-montane forest and alpine tundra & 3 & 650,413 & 99 & 1 & $<0.5$ & $\sim 6$ & $\sim 12$ & $\sim 20$ \\
\hline Rocky Mountain forests & 43 & 404,834 & 82 & 17 & 1 & $\sim 7$ & $\sim 11$ & $\sim 18$ \\
\hline Shrub steppe & 21 & 523,802 & 84 & 14 & 2 & $\sim 1$ & $\sim 6$ & $\sim 17$ \\
\hline Southern (deciduous) forests & 17 & 715,675 & 6 & 74 & 20 & - & - & - \\
\hline Southern shortgrass prairie & 2 & 205,310 & 73 & 25 & 3 & - & - & $\sim 15$ \\
\hline Subarctic boreal forest & 5 & 735,061 & 98 & 2 & $<0.5$ & $\sim 15$ & $\sim 18$ & $\sim 18$ \\
\hline Tall grasslands-prairie & 125 & 354,746 & 8 & 72 & 20 & $\sim 2$ & $\sim 4$ & $\sim 10$ \\
\hline Texan forests and grasslands & 6 & 233,098 & 13 & 66 & 21 & - & - & - \\
\hline Western forests and grasslands & 4 & 584,930 & 73 & 25 & 2 & $<1$ & $<1$ & $<1$ \\
\hline Outside historical range & 186 & - & - & - & - & - & - & - \\
\hline Total & 1,236 & $9,486,204$ & 55 & 37 & 8 & $\sim 4$ & $\sim 8$ & $\sim 12$ \\
\hline
\end{tabular}

${ }^{a}$ Current development status is measured with the human-influence index (Sanderson et al. 2002c), a precursor to the buman footprint. Values 0-9 indicate less developed, wild, and sparsely inhabited areas; 10-25, agricultural and exurban development; and $>25$ suburban and urban areas.

${ }^{b}$ Dashes in columns mean potential recovery areas were not identified.

of the landowners and the political will to make it happen, the land base is potentially available for ecological restoration.

In discussions with stakeholders after these maps were produced, these potential recovery areas were criticized as both too expansive and too constrained. For those still licking their wounds from the "Buffalo Commons" wars (Matthews 1998; Popper \& Popper 1999), anything reminiscent of such an unrestrained vision, which indiscriminately crossed public, private, and tribal lands and was not informed by landowners, is anathema. Some object to the publication of a map at all, and there is a risk of losing support by putting forth a vision that is too specific. For others, this vision is too restrained and lacks the appeal of thundering herds of buffalo migrating across the continent (e.g., Callenbach 1996). For them, the historical range and the 100-year projections should be identical.

Our perspective is that a map, with its inherent specificity, prompts discussion, debate, and substantive consideration about what is possible. This map is not etched in stone, it is printed on paper and is a working document designed to motivate discussion and inspiration. In this sense, the response to the map is more interesting than the map itself. We hope that future generations of bison advocates will gather round these inspirational sketches, not so much because of their intrinsic merits, but to argue about, use and abuse, redraw, and reimagine as their own vision for the bison unfolds.

\section{Inclusive}

Satisfying the Vermejo Statement will require including as many stakeholders as possible. For animals like bison that can be managed as both livestock and wildlife, dividing lines can be sharply drawn (List et al. 2007). If bison kept by private ranchers are not included in the ranks of herds that may contribute to ecological recovery, $96 \%$ of the world's North American bison will be lost with one stroke, and an opponent, the bison industry, will have been created instantly where an ally may have stood. Alternatively no one, including most ranchers, think a domesticated bison, looking and acting like a cow, impounded in a small feedlot, selectively bred for "more 

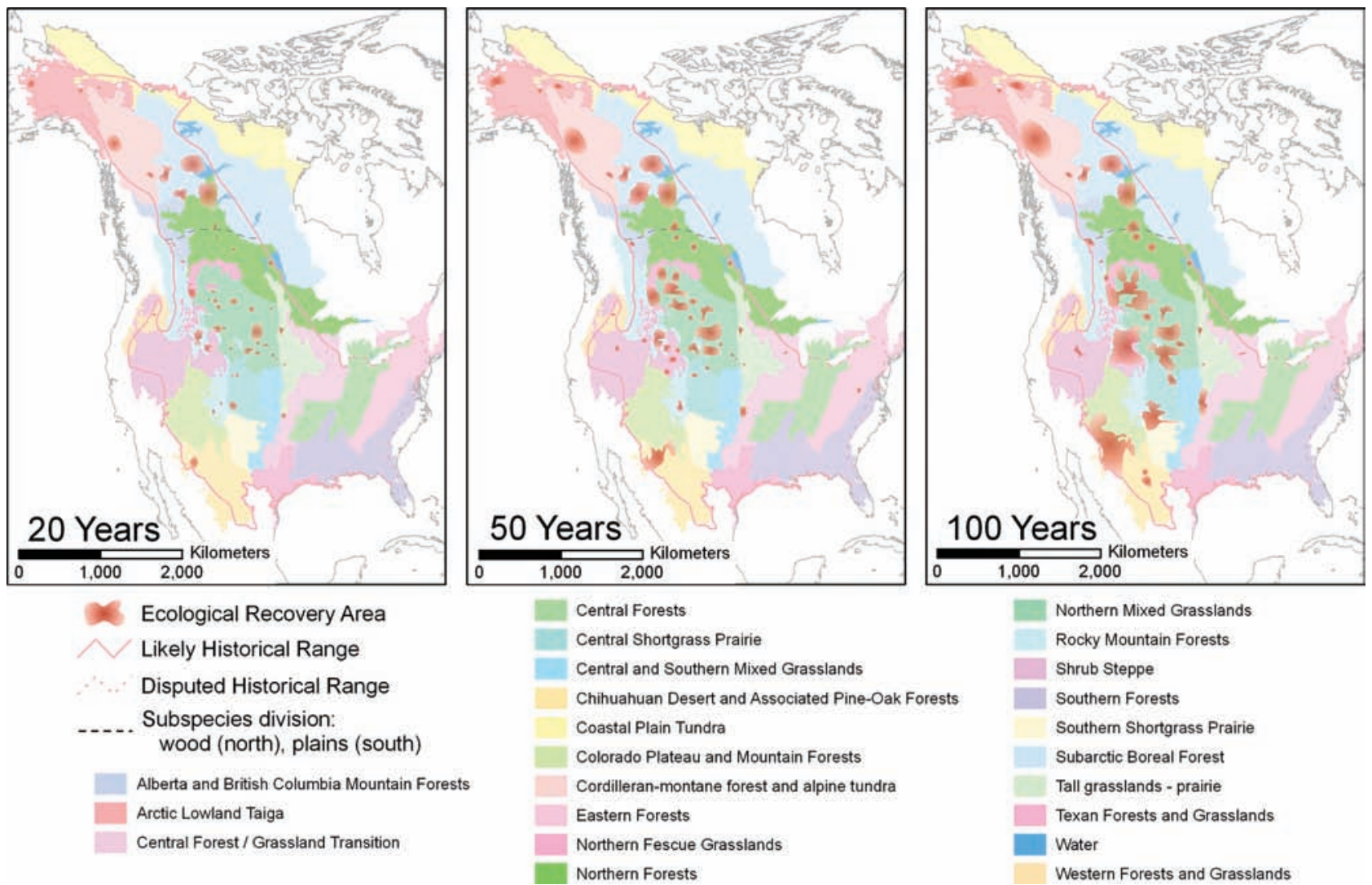

Figure 2. Distribution of potential recovery zones over the next 100 years for the North American bison. Major habitat types are indicated by colored areas in the background.

rump and less hump," should be considered ecologically recovered.

The perspective taken with the Vermejo Statement is that there is no one path to recovery; rather, there are at least 7 different ways a herd can contribute to ecological recovery. This multidimensional, continuous concept of ecological restoration is constructed as a scorecard (Table 3). Scorecards are commonly used in business to measure progress toward strategic goals (e.g., Kaplan \& Norton 1996) and are increasingly being used by conservationists (e.g., Turner 2007). Scorecards are one way to translate "qualitative" values, like those expressed in the Vermejo Statement, into more quantifiable and transparent indicators, which the public, conservationists, managers, and donors can use to measure the efficacy of conservation actions. Such explicit statements of conservation objectives are necessary for conservation to succeed (e.g., Tear et al. 2005; Sanderson 2006); however, there are concerns about how "qualitative" aspects of values can be quantified and, more troubling, how variables measured in different currencies can be combined in meaningful ways. We have not resolved these issues either and doubt whether they can be resolved "scientifically" because values, not scientific understanding, are at stake. Rather, we see these as issues the bison conservation community must resolve, as we seek to, paraphrasing
Thoreau (1854), "place foundations ... under our castles in the air."

To develop the scorecard, we took the Vermejo Statement and broke it into its component factors and defined them, quantitatively where possible, across 5 levels of contribution. In the future, points could be assigned to each level so that a summary "ecological recovery score" could be calculated for each herd when the data become available. These scores could be summed across major habitat types, across the 2 subspecies, and across the historical range of the species for broader level metrics. Over time, these as yet undeveloped, aggregate scores would increase as on-the-ground conservation efforts moved us collectively toward the vision.

Important questions remain about the details of how such a scorecard could be implemented; we do not take a position on how or whether factors should be weighted relative to each other or subfactors within the larger factors. All the factors listed seem important. Nor do we have the data to score any of the 1236 herds in our database. Additional research and input from managers will be required to bring more precision to the definitions. This research agenda should embrace not only ecologists, worried about how "natural selection" or "ecological interactions" are defined, but also political scientists, educators, and producers who can help define, respectively, 


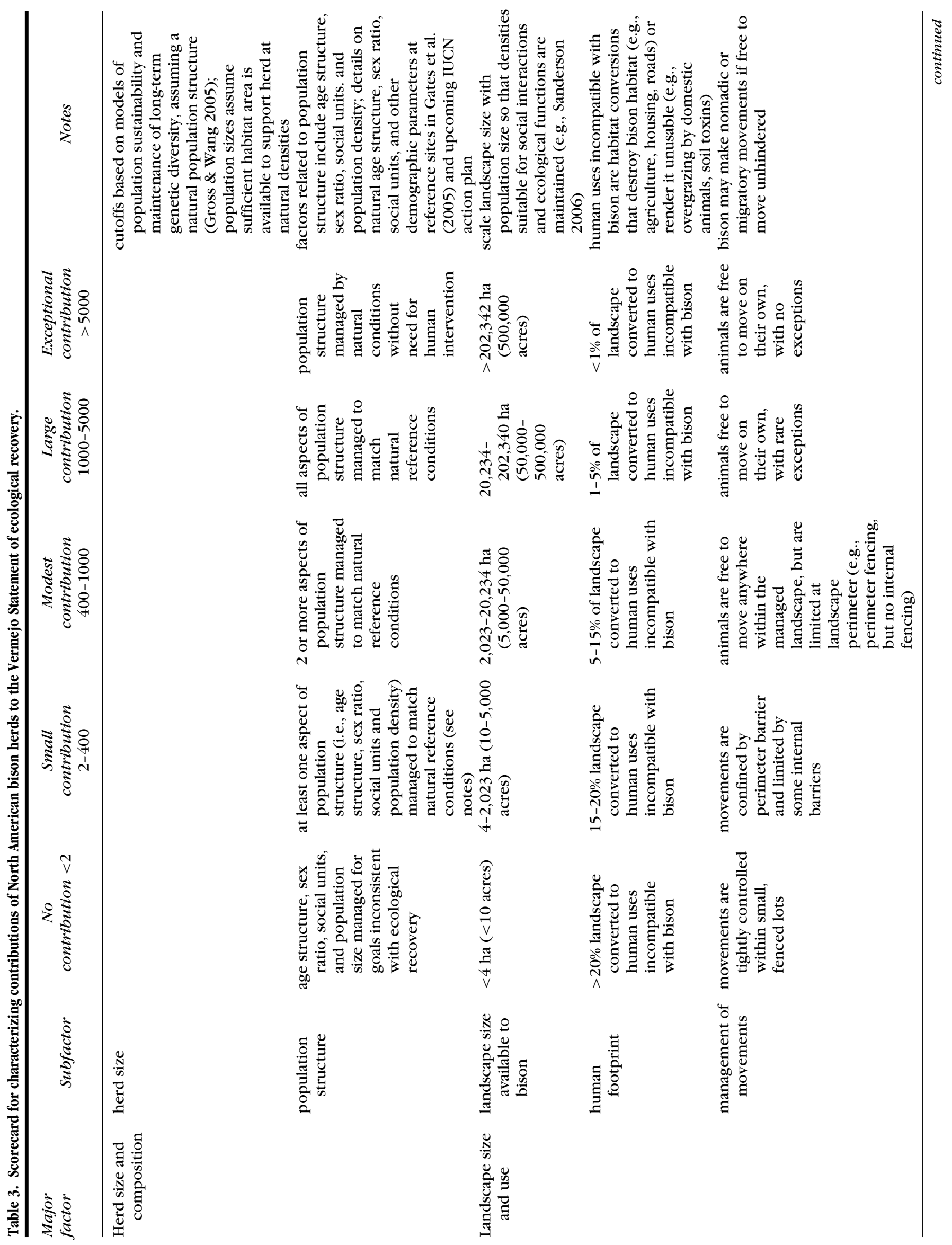




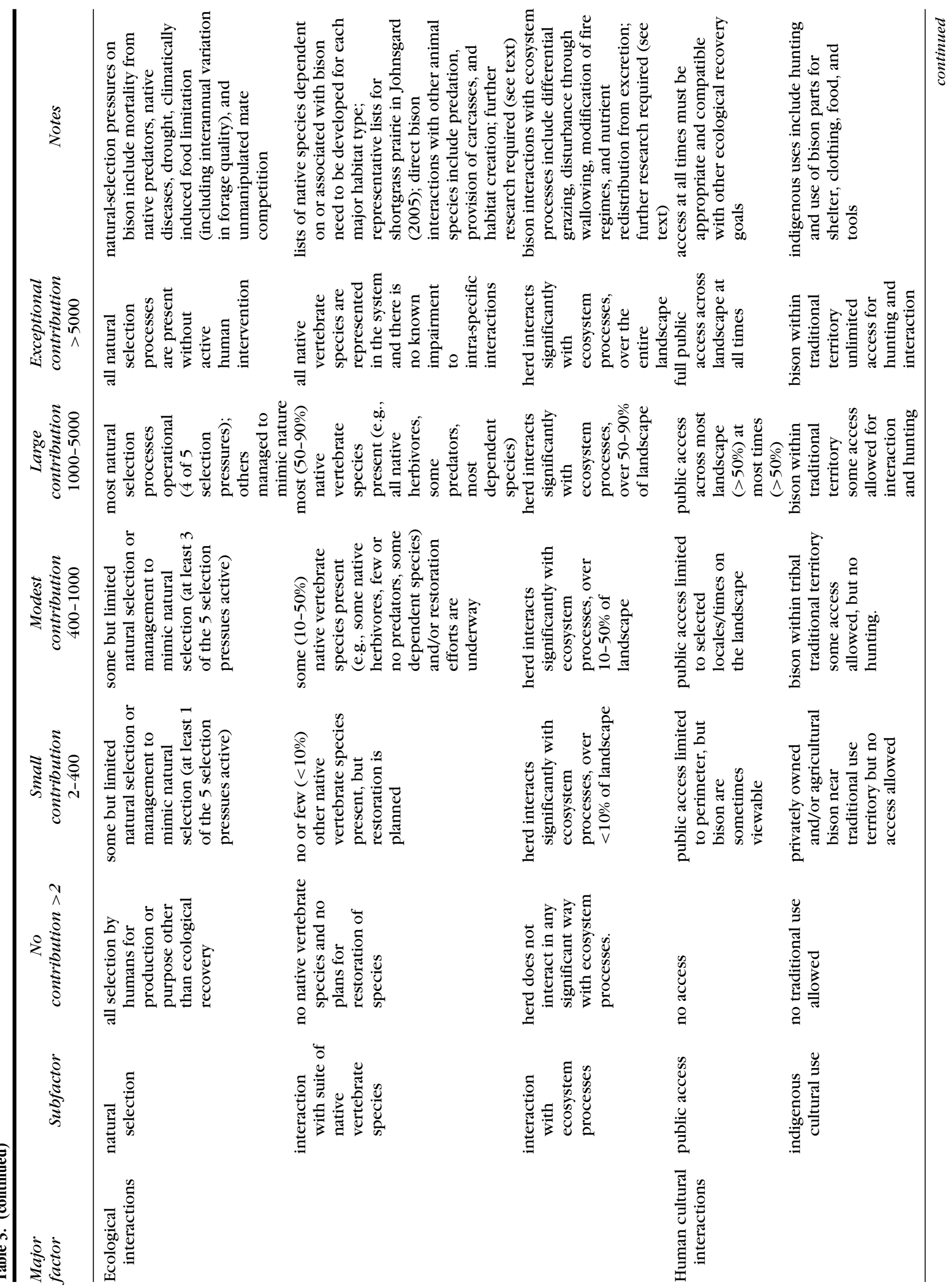




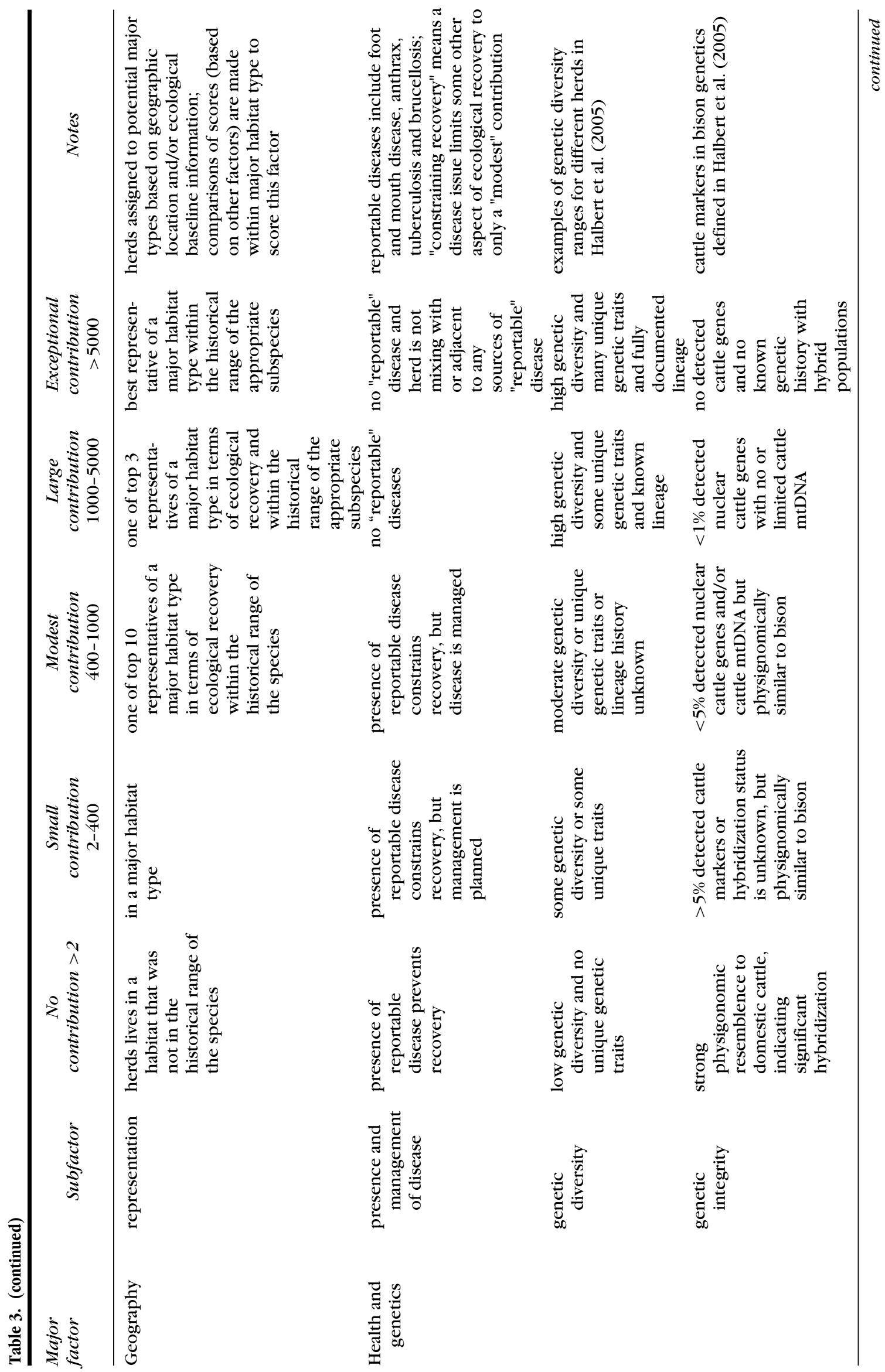




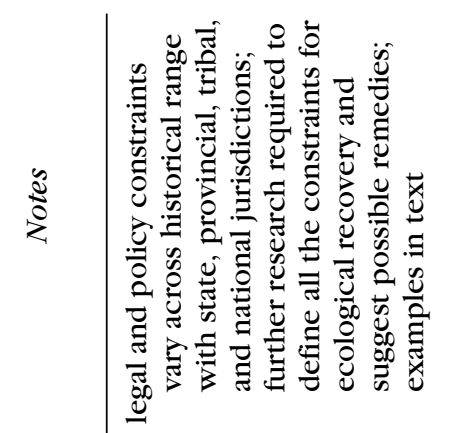

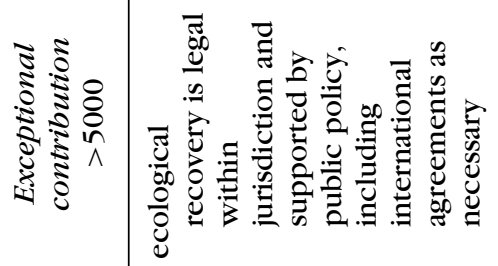

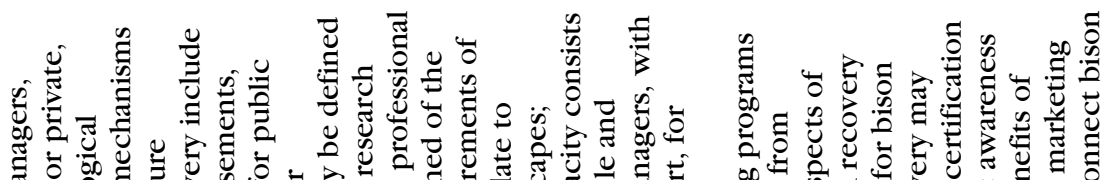

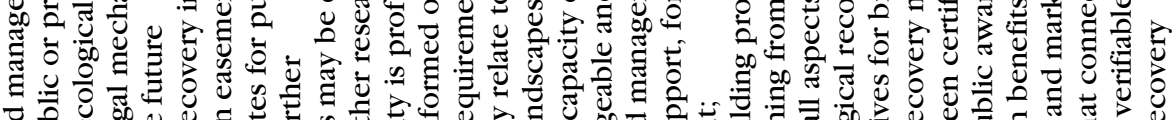

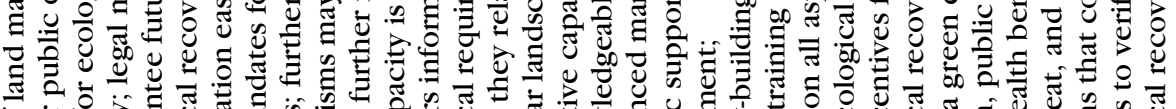

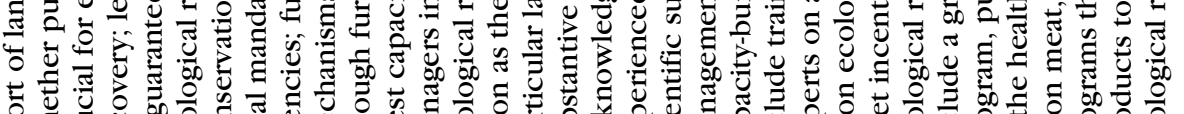

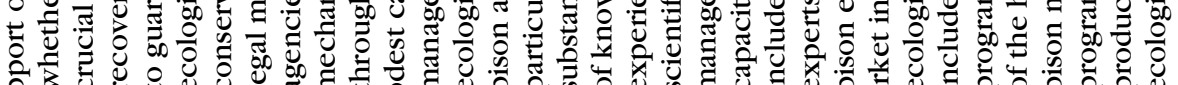

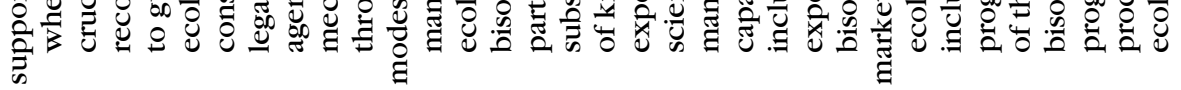

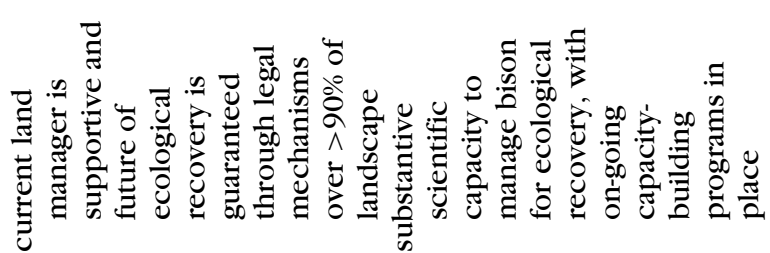




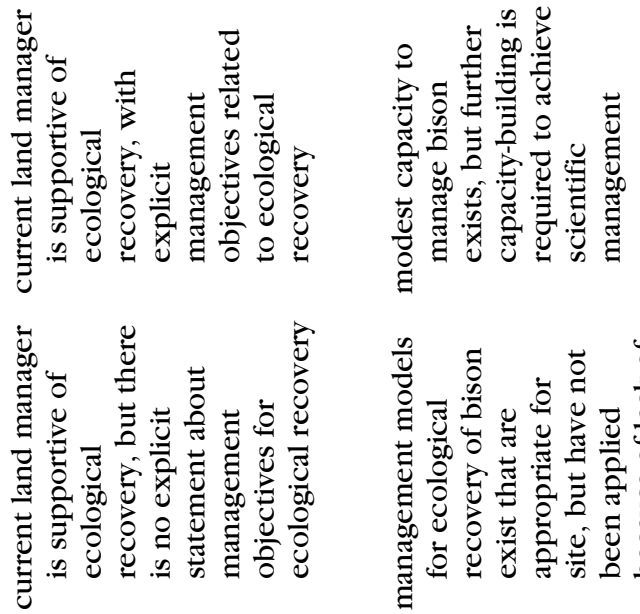

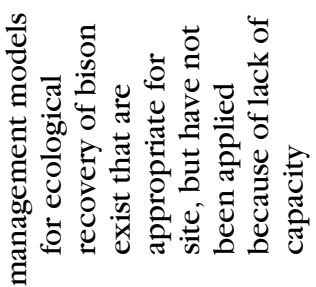
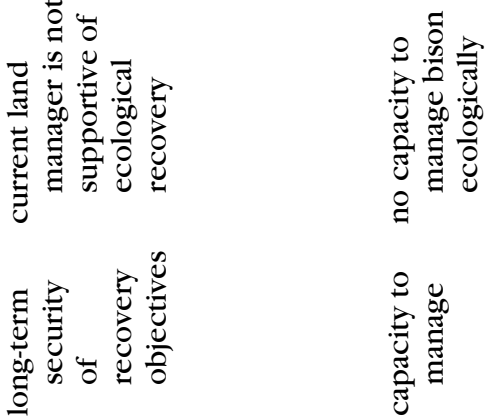

胥蒫

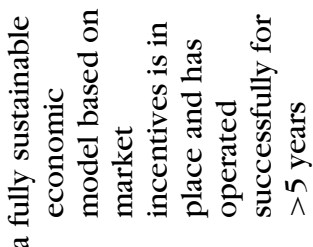

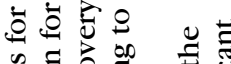

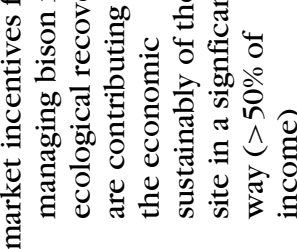

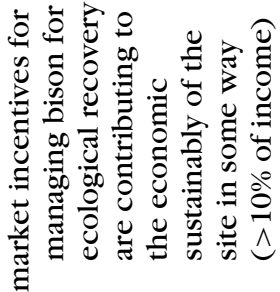

훙ㅎㅁ

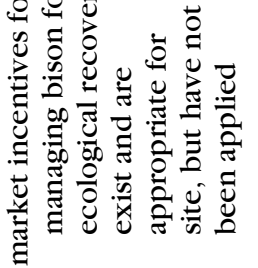

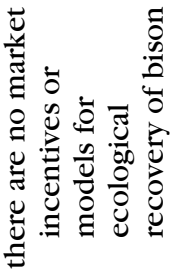

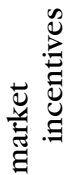


what "a supportive policy framework," "education and outreach," and "market incentives" mean for ecological recovery. In short, the scorecard needs more work to be made operational.

Nevertheless, there were several advantages to creating Table 3. First, because it is more specific than the statement itself, it provides depth without overburdening the vision with suffocating detail. Second, it begins to translate qualitative statements into quantitative goals that can be used to measure the success of ecological recovery at multiple scales. Third, a more-developed version of this scorecard has the potential for use in certification of bison products from herds that are "ecologically restored." Finally, the scorecard allows bison managers to visualize a way in which their herds could contribute to the larger vision of ecological recovery, while explicitly recognizing the constraints they face.

\section{Fulfilling of Conservation Values}

Restoration is not a monolithic endeavor motivated by a single set of values (Clewell \& Aaronson2006); on the contrary, people have many different reasons to conserve and restore animals and many different paths to realizing their values (Sanderson 2006.) By raising the tent of our vision high and pitching it broadly, we believe we can bring together a diversity of stakeholders working together toward a common goal, even if individuals are motivated by their own values.

Our vision embraces 3 fundamental values for species conservation: ecological representation, ecological functionality, and the connection of people to nature. The third value was strongly advocated by the Native American and First Nation authors of the Vermejo Statement and endorsed by all. Indigenous cultures in the Americas have a long and special history of spiritual connection to bison, which is reflected in their cultural narratives and personal accounts. Original Americans in our meetings spoke passionately about their spiritual relationships with bison. In their own way North Americans of all ethnic origins have cultural relationships with bison based on aesthetics, ethics, nostalgia, and sense of place. We discovered in our meetings, many of the people who keep bison today do so for reasons that transcend economics, class, ethnicity, and nationality. These connections are shared by people who live near bison and those that experience bison while visiting from places faraway.

But we also acknowledge that, although we want to be connected to them, bison are already dependent on us. Today the population size and distribution of most species are culturally determined (Weber 2005), a simple consequence of the relative abundance of people and the depth and breadth of our mark on the planet (Sanderson et al. 2002c). People prefer some species and find coexistence with others perilous or inconvenient; bison have the luck of being both, and that tension plays out in the arguments for their conservation and management.

Part of what motivates people to conservation is the existence of the animal and the existence of animals interacting with the environment (Redford \& Feinsinger 2001). Ecological functionality connects species to their ecosystem context (Soulé et al. 2003). In the case of species like the bison, we believe these connections are fundamental to restoration (Table 1). A tiger in a cage does not satisfy and neither does a bison in a corral. But bison grazing down the grass, spreading buffalo chips far and wide, interacting with other native species, living in large herds, and returning to earth when they die-these are animals that are integral to their landscapes. Conserving bison and conserving landscapes through bison are inseparable notions.

Ecological representation puts interactions in a geographic context, ensuring that the quality and diversity of functions across ecosystems are conserved. Most people believe that in the near term, bison conservation will occur mainly on the grasslands for plains bison and in the boreal forests for wood bison. Nevertheless, considering the entire ecological range bison once occupied allows a larger group of people to share the benefits of bison conservation. If the conservation community forgets the bison of the Arctic, or the Kentucky Buffalo Trace, then who will remember?

The downside of attempting to fulfill different goals is that sometimes goals come into conflict. People who want spiritual satisfaction from hunting buffalo may not look kindly on wolves taking their satisfaction first. Should a conservation organization invest in building a population in South Dakota to create grassland heterogeneity or should it instead reintroduce a new wild population in the Yukon? When does economics trump aesthetics? When does aesthetics trump function? Whatever choices each individual or individual organization makes, and we all may make different choices, the vision must allow as many as possible to contribute.

\section{Ambitious}

We live in a time of diminished expectations for nature, when baseline concepts about nature no longer reflect the abundance, variety, and spectacular phenomena that once existed (Jackson 2001). Moreover, the onslaught of bad environmental news, from climate change to species extinction, has soured the public on conservation, and too often, conservation biologists. The public wants good news about the environment, and they want solutions that work, especially solutions that do not cost them much, make them healthier and happier, and support their current way of life. 
The only way forward is for conservation biologists to be generous and inclusive. There are over 6.5 billion people in the world; for our efforts to succeed, we are going to need their help and cooperation-across cultures, economies and nationalities (e.g., Johns 2005). This generosity to others includes a willingness to listen, an ability to embrace the alternative perspectives, and a flexibility that presupposes change, patience, and a belief in our common humanity (Kellert \& Farnham 2002). Generosity to ourselves means not selling our vision short. Rather, we need to say what we want, what is enough, what we will do to meet these ends, and, thus, engage the cultural and political conversations that are shaping our planet.

We think the Vermejo Statement captures this ambition and builds on the historical context of the North American bison. Saving the buffalo has been billed as one of the great conservation stories of the 20th century (Waldman 2001; NBA 2006), and for the goal of preventing imminent extinction, it has been a success. But conservation is more than preventing absence, it is also about creating presence: the presence of full, functioning nature that sustains itself and sustains humans as a unique part of that nature. The Vermejo Statement presents a vision of great herds, vast landscapes, and reconnected peoples and suggests that with time, space, generosity, inclusivity, and a little ambition, we might succeed again.

\section{Closing Remarks}

We hope our essay marks the beginning of the "second chance" for bison that Freese et al. (2007) describe; moreover, we believe that the cause of bison ecological recovery will provide a rallying point for other species restoration efforts. The next step that needs to be taken is for the Vermejo vision to be integrated into bison management at local, state/provincial, national, and ecoregional levels so that the vision informs and coordinates all efforts, from how individual ranchers work their bison to national biodiversity plans. An integral part of this effort will be a broadly inclusive revision of the scorecard.

In the midst of our optimism, we recognize that the reality of achieving this vision requires the kind of stubborn persistence that late 19th century conservationists brought to the cause. We live in a time of minimal expectations for nature, not maximal, inhabiting a planet more modified by human activity than ever before (McNeill 2000), with climate change only the latest and greatest of the new threats. Although we can list ecological functions of bison (Table 1), we have yet to discover ways to fully define and measure them. Although we can make general statements about the land base (Table 2), we need to identify opportunities across the range with willing parties. Although we will continue to grapple with difficult problems related to disease, genetics, legal status, and economics, we need a common metric to chart our progress (Table 3). And we need a shared vision; if we had not looked out 100 years, we might not have thought it possible at all.

The larger issues in this essay relate to clearly articulating what conservation biologists want for the nature that we love (Sanderson 2006). Not stating the goals or allowing conditions to dictate what is possible seems an unlikely path to success. Rather, clearly stating goals and then working toward them, as the American Bison Society did in 1905, seems a more effective way forward. It seems odd that in nearly every other arena of human endeavor 21st century societies are generally looking forward to more-improved well-being, enriched spiritual lives, greater wealth and power-whereas most nature conservation efforts continue to be ad hoc, small scale, and short term; that is, there is less rather than more. When it comes to species conservation, especially for species as iconic and important as the bison, we can do better. We can be clear about our science and our values; we can be expansive, building communities and finding friends; and we can be persistent in delivering on our vision for nature.

\section{Acknowledgments}

The Wildlife Conservation Society, in honor of the 100th anniversary of the American Bison Society, supported this work with help from L. Linden. The ESRI Conservation Program, Prospect Hill Foundation, Wind River Ranch, Vermejo Park Ranch, World Wildlife Fund-US, and The Nature Conservancy provided additional support. T. Bean prepared the maps; J. Ray, E. Reuter, and 3 anonymous reviewers provided helpful comments on the manuscript. The opinions expressed reflect only the opinions of the authors and not necessarily the supporting institutions.

\section{Literature Cited}

AZA (Association of Zoos and Aquariums). 2006. Association of zoos and aquariums, Silver Spring, Maryland. Available from http://www. aza.org/ (accessed November 2006).

Boyd, D. P. 2003. Conservation of North American bison: status and recommendations. MS thesis. University of Calgary, Calgary, Alberta.

Callenbach, E. 1996. Bring back the buffalo! A sustainable future for America's Great Plains. University of California Press, Berkeley.

Clewell, A. F., and J. Aaronson. 2006. Motivations for the restoration of ecosystems. Conservation Biology 20:420-428.

Coppedge, B. R., and J. H. Shaw. 1997. Effects of horning and rubbing behavior by bison (Bison bison) on woody vegetation in a tallgrass prairie landscape. American Midland Naturalist 138:189-196.

Coppedge, B. R., S. D. Fuhlendorf, D. M. Engle, B. J. Carter, and J. H. Shaw. 1999. Grassland soil depressions: relict bison wallows or inherent landscape heterogeneity? The American Midland Naturalist 142:382-392.

Fischer, L. A., and C. C. Gates. 2005. Competition potential between sympatric woodland caribou and wood bison in southwestern 
Yukon, Canada. Canadian Journal of Zoology-Revue Canadienne De Zoologie 83:1162-1173.

Forrest, S. C., H. Strand, W. H. Haskins, C. Freese, J. Proctor, and E. Dinerstein. 2004. Oceans of grass: a conservation assessment for the Northern Great Plains. Northern Plains Conservation Network and World Wildlife Fund Northern Great Plains Program. World Wildlife Fund, Bozeman, Montana.

Frank, D. A. and R. D. Evans. 1997. Effects of native grazers on grassland N cycling in Yellowstone National Park. Ecology 78:2238-2248.

Freese, C. H. 1998. Wild species as commodities: managing markets and ecosystems for sustainability. Island Press, Washington, D.C.

Freese, C. H., et al. 2007. Second chance for the plains bison. Biological Conservation 136:175-184.

Fuhlendorf, S. D., and D. M. Engle. 2001. Restoring heterogeneity on rangelands: ecosystem management based on evolutionary grazing patterns. BioScience 51:625-632.

Gates, C. C., B. Stelfox, T. Muhly, T. Chowns, and R. J. Hudson. 2005. The ecology of bison movements and distribution in and beyond Yellowstone National Park. National Park Service, Yellowstone National Park, Wyoming. Available from http://www.nps.gov/yell/ parkmgmt/gates.htm (accessed February 2007).

Green, G. I., D. J. Mattson, and J. M. Peek. 1997. Spring feeding on ungulate carcasses by grizzly bears in Yellowstone National Park. Journal of Wildlife Management 61:1040-1055.

Gross, J. E., and G. Wang. 2005. Effects of population control strategies on retention of genetic diversity in National Park Service bison (Bison bison) herds. Final report. Yellowstone Research Group, U.S. Geological Survey-Biological Resources Division, Bozeman, Montana.

Haines, F. 1995. The buffalo: the story of American Bison and their hunters from prehistoric times to the present. University of Oklahoma Press, Norman.

Halbert, N. D., T. J. Ward, R. D. Schnabel, J. F. Taylor, and J. N. Derr. 2005. Conservation genomics: disequilibrium mapping of domestic cattle chromosomal segments in North American bison populations. Molecular Ecology 14:2343-2362.

Hall, E. R., and K. R. Kelson. 1959. The mammals of North America. Ronald Press, New York.

Hawley, A. W. L., and H. W. Reynolds. 1987. Management alternatives for ungulate production in the Slave River Lowlands. Pages 63-66 in H. Reynolds and A. Hawley, editors. Bison ecology in relation to agricultural development in the Slave River Lowlands N.W.T. Occasional paper 63. Minister of Supply and Services Canada, Ottawa, Ontario.

Hornaday, W. T. 1889. The extermination of the American Bison. 1887 annual report of the board of regents. Smithsonian Institution, Washington, D.C.

Isenberg, A. C. 2000. The destruction of the bison. Cambridge University Press, Cambridge, United Kingdom.

Jackson, J. B. C. 2001. What was natural in the coastal ocean? Proceedings of the National Academy of Sciences of the United States of America 98:5411-5418.

Johns, D. 2005. The other connectivity: reaching beyond the choir. Conservation Biology 19:1681-1682.

Johnsgard, P. A. 2005. Prairie dog empire: a saga of the shortgrass prairie. University of Nebraska Press, Lincoln, Nebraska.

Kaplan, R. S., and D. P. Norton. 1996. The balanced scorecard: translating strategy into action. Harvard Business School Press, Cambridge, Massachusetts.

Kellert, S. R., and T. J. Farnham. 2002. The good in nature and humanity: connecting science, religion, and spirituality with the natural world. Island Press, Washington, D.C.

Knapp, A. K., J. M. Blair, J. M. Briggs, S. L. Collins, D. C. Hartnett, L.C. Johnson, and E. G. Towne. 1999. The keystone role of bison in North American tallgrass prairie-bison increase habitat heterogeneity and alter a broad array of plant, community, and ecosystem processes. Bioscience 49:39-50.
Laliberte, A. S., and W. J. Ripple. 2004. Range contractions of North American carnivores and ungulates. BioScience 54:123-138.

List, R., G. Ceballos, C. Curtin, P. J. P. Gogan, J. Pacheco, and J. Truett. 2007. Historic distribution and challenges to bison recovery in the northern Chihuahuan Desert. Conservation Biology 21:14871494.

MacDonald, D. W. 2006. The encyclopedia of mammals. Facts on File, Natural Science Library, New York.

McNeill, J. R. 2000. Something new under the sun: an environmental history of the twentieth-century world. W.W. Norton, New York.

Manning, A. D., D. B. Lindenmayer, and J. Fischer. 2006. Stretch goals and backcasting: approaches for overcoming barriers to large-scale restoration. Restoration Ecology 14:487-492.

Marcot, B. G., and M. Vander Heyden. 2001. Key ecological functions of wildlife species. Pages 168-186 in D. H. Johnson and T. A. O'Neil, technical coordinators. Wildlife-habitat relationships in Oregon and Washington. Oregon State University Press, Corvallis.

Matthews, M. 1998. Bison comeback meets resistance on the ground. High Country News, 8 June. Available from http://www.hcn.org/ servlets/hcn.Article?article_id=4211 (accessed November 2006).

National Bison Association. 2006. National Bison Association home page. Available from http://www.bisoncentral.com/ (accessed November 2006).

Parmesan, C. 2006. Ecological and evolutionary responses to recent climate change. Annual Review of Ecology and Systematics 37:637639.

Popper, D. E., and F. J. Popper. 1999. The Buffalo Commons: metaphor as method. Geographical Review 89:491-510.

Redford, K. H., and E. Fearn. 2006. The ecological future of the North American Bison. Wildlife Conservation Society, Bronx, New York.

Redford, K. H., and P. Feinsinger. 2001. The half-empty forest: sustainable use and the ecology of interactions. Pages 370-399 in J. Reynolds, G. M. Mace, K. H. Redford, and J. G. Robinson, editors. Conservation of exploited species. Cambridge University Press, Cambridge, United Kingdom.

Reynolds, H. W., C. C. Gates, and R. D. Glaholt. 2003. Bison (Bison bison). Pages 1009-1060 in G. A. Feldhamer, B. C. Thompson, and J. A. Chapman, editors. Wild mammals of North America: biology, management and conservation. Johns Hopkins University Press, Baltimore, Maryland.

Reynolds, J., G. M. Mace, K. H. Redford, and J. G. Robinson. 2001. Conservation of Exploited Species. Cambridge University Press, London.

Ricketts, T. H., et al. 1999. Terrestrial ecoregions of North America: a conservation assessment. Island Press, Washington, D.C.

Rostlund, E. 1960. The geographic range of the historic bison in the Southeast. Annals of the Association of American Geographers 50:395-407.

Sanderson, E. W. 2006. How many animals do we want to save? The many ways of setting population target levels for conservation. BioScience 57:911-922.

Sanderson, E. W., K. H. Redford, A. Vedder, S. E. Ward, and P. B. Coppolillo. 2002a. A conceptual model for conservation planning based on landscape species requirements. Landscape and Urban Planning 58:41-56.

Sanderson, E. W., K. H. Redford, C.-L. B. Chetkiewicz, R. A. Medellin, A. Rabinowitz, J. G. Robinson, and A. B. Taber. 2002b. Planning to save a species: the jaguar as a model. Conservation Biology 16:5872.

Sanderson, E. W., M. Jaiteh, M. A. Levy, K. H. Redford, A. V. Wannebo, and G. Woolmer. 2002c. The human footprint and the last of the wild. BioScience 52:891-904.

Shaffer, M. L., and B. A. Stein. 2000. Safeguarding our precious heritage. Pages 301-322 in B. A. Stein, L. S. Kutner, and J. S. Adams, editors. Precious heritage: the status of biodiversity in the United States. Oxford University Press, Oxford, United Kingdom.

SER (Society for Ecological Restoration International), Science \& Policy Working Group. 2004. The ser international primer on ecological 
restoration. SER, Tucson, Arizona. Available from www.ser.org (accessed June 2007).

Shaw, J. H. 2000. How many bison originally populated western rangelands? Bison World 25:38-41.

Shepard, P. 1996. The others: how animals made us human. Island Press, Washington, D.C.

Smith, D. W., L. D. Mech, M. Meagher, W. E. Clark, R. Jaffe, M. K. Phillips, and J. A. Mack. 2000. Wolf-bison interactions in Yellowstone National Park. Journal of Mammalogy 81:1128-1135.

Soulé, M. E., J. A. Estes, J. Berger, and C. Martinez del Rio. 2003. Ecological effectiveness: conservation goals for interacting species. Conservation Biology 17:1238-1250.

Soulé, M. E., and J. Terborgh. 1999. The policy and science of regional conservation. Pages 1-17 in M. E. Soule and J. Terborgh, editors. Continental conservation: scientific foundations of regional reserve networks. Island Press, Washington, D.C.

Tear, T. H., et al. 2005. How much is enough? The recurrent problem of setting measurable objectives in conservation. BioScience 55:835849.
Thoreau, H. D. 1854. Walden, or life in the woods. Ticknor \& Fields, Boston.

Towne, E. G. 2000. Prairie vegetation and soil nutrients responses to ungulate carcasses. Oecologia 122:232-239.

Turner, C. R. 2007. Water beetles associated with reservoirs on Table Mountain, Cape Town: implications for conservation. Journal of Insect Conservation 11:75-83.

U.S. Department of State. 2006. Conservation efforts give historic American Bison a future. Available from http://usinfo.state.gov/ xarchives/display.html?p=washfile-english $\& \mathrm{y}=2006 \& \mathrm{~m}=\mathrm{July} \& \mathrm{x}=$ 20060726145109 abretnuh0.9105188 (accessed June 2007).

Waldman, N. 2001. They came from the Bronx: how the buffalo were saved from extinction. Boyds Mill Press, Honesdale, Pennsylvania.

Weber, B. 2005. Culturally determined wildlife populations: the problem of the designer ark. Pages 233-239 in Wildlife Conservation Society, editor. State of the wild, 2006: a global portrait of wildlife, wildlands and oceans. Island Press, Washington, D.C.

Weber, B. 2006. Ecological recovery of the American bison. Wildlife Conservation 109:32-39.



